University of Wollongong

Research Online

Faculty of Engineering and Information

Faculty of Engineering and Information

Sciences - Papers: Part B

Sciences

2019

\title{
Mining phosphorus from anaerobically treated dairy manure by forward osmosis membrane
}

Biplob K. Pramanik

Royal Melbourne Institute of Technology, biplobkp@uow.edu.au

Faisal I. Hai

University of Wollongong, faisal@uow.edu.au

Ashley Ansari

University of Wollongong, ashleyz@uow.edu.au

Felicity Roddick

Royal Melbourne Institute of Technology

Follow this and additional works at: https://ro.uow.edu.au/eispapers1

Part of the Engineering Commons, and the Science and Technology Studies Commons

Research Online is the open access institutional repository for the University of Wollongong. For further information contact the UOW Library: research-pubs@uow.edu.au 


\title{
Mining phosphorus from anaerobically treated dairy manure by forward osmosis membrane
}

\author{
Abstract \\ We investigated the effect of draw solution type on the forward osmosis (FO) performance for enriching \\ nutrients from anaerobically treated dairy manure (ATDM) followed by chemical precipitation for \\ phosphorus recovery as struvite crystal. The FO membrane significantly rejected COD $(>97 \%)$ and \\ phosphate (>98\%) whereas there was only $70 \%-73 \%$ and $73 \%-76 \%$ rejection of ammonia-nitrogen and \\ total nitrogen, respectively. The draw solution type had little impact on the retention of the \\ aforementioned wastewater constituents by the FO membrane. At $60 \%$ water recovery, a water flux \\ decline of $82 \%-96 \%$ was observed due to increasing contaminant concentration in the concentrated feed \\ solution. Water flux decline was less for $\mathrm{MgCl} 2$ than EDTA-2 $\mathrm{Na}$ and $\mathrm{NaCl}$ as draw solutes. On the contrary, \\ the reverse solute flux was higher for $\mathrm{NaCl}$ than $\mathrm{MgCl} 2$, which in turn was higher than EDTA-2Na. Pre- \\ concentration of ATDM by FO facilitated struvite precipitation. $\mathrm{MgCl} 2$ as the draw solute provided a higher \\ purity of struvite than EDTA-2 $\mathrm{Na}$ and $\mathrm{NaCl}$. This is because when $\mathrm{MgCl} 2$ was used as the draw solute, the \\ reverse salt flux of magnesium to the concentrated ATDM provided favourable conditions for struvite \\ crystal formation. This study demonstrates the technical feasibility of phosphorus recovery from ATDM \\ using the FO process.

\section{Disciplines} \\ Engineering | Science and Technology Studies

\section{Publication Details} \\ Pramanik, B. Kumar., Hai, F. I., Ansari, A. J. \& Roddick, F. A. (2019). Mining phosphorus from anaerobically \\ treated dairy manure by forward osmosis membrane. Journal of Industrial and Engineering Chemistry, 78 \\ 425-432.
}




\section{Research Highlights}

* Phosphorus recovery from dairy manure using the FO process is demonstrated

* A water flux decline of $82-96 \%$ was observed at $60 \%$ water recovery by FO

* Water flux decline was less for $\mathrm{MgCl}_{2}$ than EDTA-2Na and $\mathrm{NaCl}$ as draw solutes

* $\mathrm{MgCl}_{2}$ as a draw solute provided a higher purity of struvite than EDTA-2Na and $\mathrm{NaCl}$

* Draw solution has little effect on the retention of the contaminants by the FO membrane 
Mining phosphorus from anaerobically treated dairy manure by forward osmosis membrane

Biplob Kumar Pramanik ${ }^{a^{*}}$, Faisal I. Hai ${ }^{\text {b }}$, Ashley J. Ansari ${ }^{\text {b }}$, Felicity A. Roddick ${ }^{\text {a }}$

${ }^{a}$ School of Engineering, RMIT University, Melbourne, VIC 3000, Australia

${ }^{\mathrm{b}}$ Strategic Water Infrastructure Laboratory, School of Civil, Mining and Environmental Engineering, University of Wollongong, Wollongong, NSW 2522, Australia

Corresponding author Email: biplob.pramanik@rmit.edu.au;

Telephone number: +61399259419 


\begin{abstract}
We investigated the effect of draw solution type on the forward osmosis (FO) performance for enriching nutrients from anaerobically treated dairy manure (ATDM) followed by chemical precipitation for phosphorus recovery as struvite crystal. The FO membrane significantly rejected COD (>97\%) and phosphate (>98\%) whereas there was only $70 \%-73 \%$ and $73 \%-76 \%$ rejection of ammonia-nitrogen and total nitrogen, respectively. The draw solution type had little impact on the retention of the aforementioned wastewater constituents by the FO membrane. At $60 \%$ water recovery, a water flux decline of $82 \%-96 \%$ was observed due to increasing contaminant concentration in the concentrated feed solution. Water flux decline was less for $\mathrm{MgCl}_{2}$ than EDTA-2 $\mathrm{Na}$ and $\mathrm{NaCl}$ as draw solutes. On the contrary, the reverse solute flux was higher for $\mathrm{NaCl}$ than $\mathrm{MgCl}_{2}$, which in turn was higher than EDTA-2Na. Pre-concentration of ATDM by FO facilitated struvite precipitation. $\mathrm{MgCl}_{2}$ as the draw solute provided a higher purity of struvite than EDTA-2Na and $\mathrm{NaCl}$. This is because when $\mathrm{MgCl}_{2}$ was used as the draw solute, the reverse salt flux of magnesium to the concentrated ATDM provided favourable conditions for struvite crystal formation. This study demonstrates the technical feasibility of phosphorus recovery from ATDM using the FO process.
\end{abstract}

Keywords: Anaerobically treated dairy manure, draw solution, forward osmosis, contaminants rejection, struvite recovery

\title{
1. Introduction
}

Management of dairy manure represents one of the significant challenges for the development of the livestock industry due to the production of large volumes of wastewater 
characterised by high organic and nutrient contents [1]. Discharge of the nutrients i.e., nitrogen and phosphorous into the aquatic environment is undesirable as they are the key sources of eutrophication in the water environment. On the other hand, both phosphorus and nitrogen are necessary for agricultural production [2]. Dairy manure has a high nutrient content with typical phosphorus concentration varying from $50 \mathrm{mg} / \mathrm{L}$ to $350 \mathrm{mg} / \mathrm{L}[3,4]$. Hence the concept of recovering phosphorus from dairy manure is a 'renewable' alternative for delivering sustainable phosphorus supplies as well as complying with the increasingly stringent effluent discharge regulations.

Phosphorus has usually been recovered as struvite crystal $\left(\mathrm{MgNH}_{4} \mathrm{PO}_{4} \cdot 6 \mathrm{H}_{2} \mathrm{O}\right)$ via chemical precipitation [5, 6] from different sources such as wastewater [7], anaerobically digested sludge [8-10], and urine [11]. Recently, Oliveira et al. [12] investigated phosphorous extraction from dairy manure. Notably, a pre-treatment is required to solubilise the phosphorus content in dairy manure in order to implement the struvite precipitation process. This is because $65-70 \%$ of the phosphorus in dairy manure occurs in particulate form [13, 14]. To solubilise the particulates, dairy manure can mainly be anaerobically pre-treated before struvite recovery [15]. Irrespective of the pre-treatment, magnesium ion needs to be added to the solution to induce precipitation of phosphorous in the form of struvite.

Recent studies have investigated the forward osmosis (FO) process for the pre-concentration of wastewater for nutrient recovery [16]. It is an osmotically-driven process in which water passes from a solution of lower osmotic pressure into a solution of higher osmotic pressure [17]. The solution of higher osmotic pressure is known as the draw solution. The FO process has a number of benefits such as high contaminant rejection and lower fouling tendency compared to conventional pressure-driven membrane processes [18-20]. While producing 
clean water, this process can concentrate phosphate, magnesium and ammonium in the feed side to enable struvite recovery [21]. A few studies have investigated the FO process for phosphorus recovery from municipal wastewater [22, 23], urine [24] and digested sludge centrate [21, 25]. However, no study has explored the application of FO for enriching phosphorus concentration for struvite recovery from dairy manure.

Reverse solute flux is a critical phenomenon in the FO process. Ions with various diffusivities in feedwater can influence the charge characteristics of the FO membranes because of adsorption and electrostatic interactions, resulting in different extent of reverse solute flux i.e., passage of draw solute back into the feed side. Studies have investigated the impact of draw solute type on reverse solute flux during wastewater treatment by FO. Inorganic salts are commonly used as draw solutes as they are inexpensive, can create high osmotic pressure, and pose less likelihood of inducing significant internal concentration polarisation (ICP) due to their rapid diffusion and small solute size. However, these characteristics typically provide a high reverse solute flux [26]. It is noteworthy that most of the previous studies have used only one type of draw solute for the nutrient recovery. For example, Zhang et al. [24] and Xue et al. [22] used seawater brine as a draw solution for mining nutrient from municipal wastewater and urine, respectively. Xie et al. [21] used magnesium chloride as a draw solution for struvite recovery from anaerobically digested sludge centrate. Hence, the potential impacts of reverse solute flux on clean water flux and struvite recovery from dairy manure while using different draw solutes remain to be elucidated.

The purpose of this research was to investigate the application of the FO system for recovering phosphorus from anaerobically treated dairy manure effluent by integrating the process with a chemical precipitation technique. The effect of three different commonly used 
draw solutions, on FO performance was evaluated in terms of water flux, bulk organics removal and phosphate mineral recovery as struvite crystal.

\section{Materials and Methods}

\subsection{Collection of feed solution}

The dairy wastewater was collected from a commercial dairy farm in Gerringong, Wollongong, Australia. At that site, the dairy wastewater is treated by anaerobic and then aerobic ponds. Then the biologically treated effluent is released to the sewer network for further treatment at the municipal wastewater treatment plant. In this study, initially three different samples, namely, raw dairy wastewater, anaerobic pond effluent and aerobic pond effluent, were investigated. Finally, anaerobic pond effluent was used for struvite recovery, and the reason for this choice is discussed in Section 2.2. All wastewater samples were stored at $4{ }^{\circ} \mathrm{C}$. Before all tests, wastewater samples were filtered through a $100 \mu \mathrm{m}$ membrane and brought to laboratory temperature $\left(22 \pm 2^{\circ} \mathrm{C}\right)$.

\subsection{Characteristics of the dairy manure}

Data on the chemical composition of the raw dairy manure, and the anaerobic and aerobic pond effluent streams are summarised in Table 1. The concentrations of the monitored parameters in the investigated dairy manure were comparable to that in previous studies [27, 28]. Effluent from both ponds exhibited substantially reduced concentration of COD with a COD removal efficiency of $62 \%$ and $75 \%$ after anaerobic and aerobic treatment, respectively. The pre-treated wastewater had a higher $\mathrm{pH}$ than the raw wastewater. There was no removal of inorganic contents by either pond. 
Overall about $50 \%$ removal of $\mathrm{NH}_{3}-\mathrm{N}$ was achieved. This can be attributed to biological nitrification, assimilation and/or $\mathrm{NH}_{3}-\mathrm{N}$ loss due to the increased $\mathrm{pH}$ and the uncovered surface of the pond, promoting ammonia volatilisation [29]. Biological nitrification is unlikely in aerobic pond; however, $\mathrm{NH}_{3}-\mathrm{N}$ removed by gaseous ammonia stripping or its assimilation in algal biomass can occur in anaerobic pond. Orthophosphate can be released from solids into dissolved form during anaerobic treatment of the dairy manure. This counterbalanced the loss of some phosphate molecules through mineralisation, thus resulting in a consistent total concentration of $\mathrm{PO}_{4}{ }^{3-}$ after anaerobic pre-treatment. On the other hand, $\mathrm{PO}_{4}{ }^{3-}$ concentration was markedly lower in the aerobic pond. Hence, a pragmatic solution to reclaiming the phosphorus is to recover it from anaerobically treated dairy manure.

\section{Table 1}

\subsection{Experimental protocol of the FO system}

A lab-scale cross-flow filtration set-up with a flat sheet FO membrane (active filtration surface area of $50 \mathrm{~cm}^{2}$ ) was used. A schematic diagram of the lab-scale FO system is presented in Supplementary information (Figure S1). Flat sheet thin film composite (TFC) membranes were purchased from Porifera Inc, Court Hayward, USA. This membrane is made of polyamide on polysulfone support [30]. Key properties of the TFC membrane are shown in Supplementary Information (Table S1). The FO membrane cell comprised two identical blocks (feed side and draw solution side) made of acrylic plastic. Channels of effective dimensions of $36 \mathrm{~mm}$ width, $167 \mathrm{~mm}$ length and $1.4 \mathrm{~mm}$ height were engraved on both sides for the feed and draw solutions.

The FO experiments were commenced with an initial feed volume of $1.5 \mathrm{~L}$, and filtration was continued until a $60 \%$ water recovery was achieved. The initial draw solution volume was 1 
L. The solutions were recirculated at $1 \mathrm{~L} / \mathrm{min}$ by two gear pumps (Micropump, Washington, USA) regulated by rotameters. Three draw solutes, namely, sodium chloride $(\mathrm{NaCl})$, ethylenediaminetetraacetic acid disodium salt (EDTA-2Na) and magnesium chloride $\left(\mathrm{MgCl}_{2}\right)$ were compared in this study. Analytical grade chemicals were dissolved in DI water to achieve a concentration equivalent to an osmotic pressure of 90 bar. The draw solution tank was placed on a digital balance (Mettler-Toledo Inc., Hightstown, USA) to monitor the weight increment of the permeate from the feed tank to determine the water permeate flux. The draw solution gets diluted as clean water permeates through the membrane. A small amount from a concentrated draw solution $(5 \mathrm{M})$ was added to the draw solution tank to keep a constant osmotic pressure. A conductivity probe (Cole-Parmer, Illinois, USA) was submerged into the draw solution. This probe was linked to the concentrated draw solutiondosing peristaltic pump to control the concentration of draw solution. The orientation of the FO membrane for all tests was 'FO mode' i.e., active layer facing the feed solution. A $20 \mathrm{~mL}$ sample was taken from the concentrated feedwater at 15\%, 30\%, $45 \%$ and $60 \%$ water recovery for subsequent analysis. The reverse draw solute flux of each solute was calculated by recording the conductivity changes in the feed solution (DI water) over time.

\subsection{Phosphorus recovery protocol}

The concentrated feed remaining after operating the FO system for a clean water recovery of $60 \%$ was filtered $(0.45 \mu \mathrm{m}) .1 \mathrm{M} \mathrm{NaOH}$ was added to the concentrated sample to increase the $\mathrm{pH}$ to 9.5 in order to form struvite crystals. A pH of 9.5 was selected as it could facilitate the deprotonation of ammonium [5], resulting in improvemennt of the production of struvite. The concentrated solution was mixed at laboratory temperature $\left(22 \pm 1^{\circ} \mathrm{C}\right)$ for $30 \mathrm{~min}$ by a magnetic stirrer at $400 \mathrm{rpm}$. After stirring, the solution was allowed to settle for $24 \mathrm{hrs}$. The 
obtained crystals were washed with Milli-Q water and then dried in a desiccator at laboratory temperature before further analysis.

\subsection{Analytical techniques}

Chemical oxygen demand (COD), total nitrogen (TN), phosphate $\left(\mathrm{PO}_{4}{ }^{3-}\right)$, ammonia-nitrogen $\left(\mathrm{NH}_{3}-\mathrm{N}\right)$ and nitrate $\left(\mathrm{NO}_{3}^{-}\right)$were analysed using a Hach DR3900 spectrophotometer. Electrical conductivity and $\mathrm{pH}$ were determined by an Orion 4-Star Plus pH/conductivity meter (Thermo Scientific, MA). Total suspended solid (TSS) concentration was determined following the Standard Methods for the Examination of Water and Wastewater.

The concentration of calcium $\left(\mathrm{Ca}^{2+}\right)$, magnesium $\left(\mathrm{Mg}^{2+}\right)$ and sodium $\left(\mathrm{Na}^{+}\right)$was analysed by inductively coupled plasma-optical emission spectroscopy (ICP-OES 710, Agilent, Australia). Before analysis, each sample was diluted using 5\% nitric acid (Suprapur, SigmaAldrich, Australia).

The recovered crystals were characterised using scanning electron microscopy integrated with energy dispersive spectroscopy (SEM-EDS) (JSM-6490, Tokyo, Japan). The purity of the crystals was determined using X-ray diffraction (XRD) spectra (GBC MMA, Hampshire, IL). The chemical composition of the recovered product was also analysed by dissolving $1 \mathrm{~g}$ of recovered sample in $100 \mathrm{~mL}$ of $5 \% \mathrm{HNO}_{3}$ using ICP-OES and spectrophotometer.

\section{Results and Discussion}

\subsection{Impact of draw solutes on permeate water flux and reverse salt flux}

The normalised flux versus water recovery for different draw solution is shown in Figure 1a. At $60 \%$ water recovery, a water flux decline of $82 \%-96 \%$ was observed due to increased 
organic loading. There was a significantly lower flux decline for $\mathrm{MgCl}_{2}$ than EDTA-2Na as draw solution. For $\mathrm{NaCl}$, flux decline was most prominent (Figure 1a). The difference in water flux at the same osmotic pressure was likely due to the different levels of ICP induced by each draw solute $[17,31]$. It has been reported that ICP is influenced by the kinetic characteristics of the draw solute, such as diffusivity and molecular size [17].

A baseline test was performed using DI water to assess the extent of pure water flux and reverse solute flux. As shown in Figure $1 \mathrm{~b}, \mathrm{MgCl}_{2}$ provided a pure water flux of $21.12 \mathrm{~L} / \mathrm{m}^{2} \mathrm{~h}$ along with a low reverse salt flux of $7.72 \mathrm{~g} / \mathrm{m}^{2} \mathrm{~h} . \mathrm{NaCl}$ produced a pure water flux of 19.92 $\mathrm{L} / \mathrm{m}^{2} \mathrm{~h}$ which was almost similar to that for EDTA-2Na $\left(18.72 \mathrm{~L} / \mathrm{m}^{2} \mathrm{~h}\right)$. However, the reverse solute flux was significantly higher for $\mathrm{NaCl}\left(16.62 \mathrm{~g} / \mathrm{m}^{2} \mathrm{~h}\right)$ than EDTA-2Na $\left(3.69 \mathrm{~g} / \mathrm{m}^{2} \mathrm{~h}\right)$. Our data confirms more rapid back diffusion of $\mathrm{Na}^{+}$than EDTA through the membrane (Figure 1a). This may be attributed to the larger size and higher negative charge of EDTA [32].

The level of salt accumulation was inversely proportional to the extent of reverse solute flux selectivity (RSFS) due to the effects of ICP. Both $\mathrm{MgCl}_{2}$ and EDTA-2Na showed a higher RSFS than $\mathrm{NaCl}$ as draw solute (Figure 1b) while showing lower back diffusion of bulk solute through the membrane. Both $\mathrm{MgCl}_{2}$ and $\mathrm{NaCl}$ contain chloride ion, but $\mathrm{MgCl}_{2}$ exhibited higher RSFS i.e., lower reverse solute flux because of the larger electron-proton attraction for $\mathrm{Mg}^{2+}[33]$.

\section{Figure 1}

\subsection{Change in conductivity, $\mathrm{pH}$ and magnesium concentration}


With progressive water recovery, salt accumulated in the concentrated feed solution, increasing the solution conductivity (Figure 2a). This affected the clean water flux adversely. The conductivity-increase was observed to vary with the draw solution used. With $\mathrm{NaCl}$, the conductivity of the concentrated feedwater markedly increased as the recovery of water increased, whereas $\mathrm{MgCl}_{2}$ and EDTA-2Na showed a noticeably lower conductivity-increase, indicating an effective mitigation of the accumulation of salinity level in the concentrated feedwater.

The $\mathrm{pH}$ of the wastewater gradually increased for all three draw solutions due to the diffusion of proton from the feed solution to the draw solution (Figure 2b). Diffusion of proton occurs to maintain electroneutrality of the solution due to reverse solute flux [34, 35]. For EDTA$2 \mathrm{Na}$, the $\mathrm{pH}$ of the feed solution increased at a slower rate than that of the other two solutes. This can be attributed to the markedly lower reverse solute flux in case of EDTA-2Na.

The FO membrane also retained $\mathrm{Mg}^{2+}$ in the feed solution (Figure 2c). As expected, when $\mathrm{MgCl}_{2}$ was used as the draw solution, a significantly higher $\mathrm{Mg}^{2+}$ level in the feedwater as compared to EDTA-2Na and $\mathrm{NaCl}$ was detected. This was due to feed volume reduction and diffusion of $\mathrm{Mg}^{2+}$ from the draw to feed solution.

\section{Figure 2}

\subsection{Enhancement and rejection of contaminants under different draw solutions}

The concentration of $\mathrm{NH}_{3}-\mathrm{N}$ and $\mathrm{PO}_{4}{ }^{3-}$, which are two critical constituents of struvite, enriched proportionally in the feedwater with the water recovery of the FO system. The FO process could concentrate nutrients and COD up to nearly 2.5-fold (Figure 3a-e). A different 
result was reported by Ansari, Hai, Price and Nghiem [25] who found that the enhancement of $\mathrm{PO}_{4}{ }^{3-}$ reduced with the water recovery due to the removal of $\mathrm{PO}_{4}{ }^{3-}$. This was possibly because of the higher level of feedwater $\mathrm{pH}$ (8.03) compared to the current study (feedwater $\mathrm{pH}$ 6.92), resulting in calcium phosphate precipitation during the filtration process. At $60 \%$ water recovery, both $\mathrm{MgCl}_{2}$ and EDTA-2Na, compared to $\mathrm{NaCl}$, exhibited slightly greater concentration of the nutrients and COD in the ATDM.

The FO membrane could reject $97 \%-99 \%$ of COD in the feed solution. The rejection of nitrogenous compounds was variable. There was $70 \%-73 \%$ rejection of $\mathrm{NH}_{3}-\mathrm{N}$. The low rejection of $\mathrm{NH}_{3}-\mathrm{N}$ was due to the bidirectional diffusion of cations through the TFC membrane [36]. $\mathrm{NH}_{3}-\mathrm{N}$ readily diffuses through the TFC membrane from the feed to the draw solution. This is likely due to its high electrostatic attraction to the negatively charged polyamide surface [36]. Increased $\mathrm{pH}$ of the ATDM after FO-concentration also increased the equilibrium ratio of $\mathrm{NH}_{3} / \mathrm{NH}_{4}{ }^{+}$(ammonium) pair, and thus influenced the low $\mathrm{NH}_{3}-\mathrm{N}$ rejection by the TFC membrane [37]. A high rejection of $\mathrm{NO}_{3}{ }^{-}(78 \%-84 \%)$ was obtained; however, this high rejection did not affect the FO performance for TN rejection (73\%-76\%). This is because the concentration of $\mathrm{NO}_{3}{ }^{-}$was small in the $\mathrm{FO}$ feed solution. It is noted that the draw solution type had little impact on the retention of the aforementioned contaminants by the FO membrane.

There was more than $98 \%$ of $\mathrm{PO}_{4}{ }^{3-}$ rejection at $60 \%$ water recovery by the FO membrane for all draw solutions. A similarly high rejection efficiency of $\mathrm{PO}_{4}{ }^{3-}$ was reported by Wang, Zheng, Tang, Wang and Wu [38] for municipal wastewater and by Zhang, She, Chang, Tang and Webster [24] for urine. Both steric hindrance and electrostatic repulsion play a role here [22]. Notably, the difference in rejection of $\mathrm{PO}_{4}{ }^{3-}$ and $\mathrm{NH}_{3}-\mathrm{N}$ by $\mathrm{FO}$ was due to the effect of 
hydrated radius of these ions [39]. According to Kiriukhin and Collins [40], compared to $\mathrm{NH}_{4}{ }^{+}, \mathrm{PO}_{4}{ }^{3-}$ has a larger hydrated radius $(0.339 \mathrm{~nm}$ vs. $0.104 \mathrm{~nm})$ and a smaller diffusion coefficient $\left(0.44 \times 10^{-9} \mathrm{~m}^{2} / \mathrm{s}\right.$ vs $1.96 \times 10^{-9} \mathrm{~m}^{2} / \mathrm{s}$ ), which can explain the greater rejection of $\mathrm{PO}_{4}{ }^{3-}$ by the $\mathrm{FO}$ membrane (Figure 3).

\section{Figure 3}

\subsection{Phosphorus recovery as struvite using chemical precipitation}

The increased $\mathrm{pH}$ and the enrichment of $\mathrm{PO}_{4}{ }^{3-}, \mathrm{NH}_{3}-\mathrm{N}$ and $\mathrm{Mg}^{2+}$ in the feed solution following FO operation provide favourable conditions for struvite precipitation by improving the precipitation kinetics. The precipitated solids were analysed to identify the crystal structure, morphology and element composition. The SEM image revealed that the precipitated crystals were of a typical orthorhombic structure (Figure 4a), which is similar to the pure struvite crystal standard. EDS analysis of the recovered solids confirmed that the materials contain $\mathrm{P}$ and $\mathrm{Mg}$ which are also the major elements of struvite crystal. EDS did not detect nitrogen as it is a 'light' element i.e., possesses low atomic number. The peak intensity of $\mathrm{P}$ and $\mathrm{Mg}$ in the EDS spectrum was higher for the $\mathrm{MgCl}_{2}$ draw solution than the EDTA$2 \mathrm{Na}$ or $\mathrm{NaCl}$ draw solutions. However, as shown by the EDS spectra of two sites on the crystal, the elements were homogenously distributed (Figure 4b).

\section{Figure 4}

The peak intensity of the elements for the $\mathrm{MgCl}_{2}$ draw solution was closer to that of the struvite standard compared to the EDTA-2Na and $\mathrm{NaCl}$ draw solutions (Figure 5a). When $\mathrm{MgCl}_{2}$ was used as the draw solution in the $\mathrm{FO}$ process, the reverse $\mathrm{Mg}^{2+}$ diffusion substantially enhanced the $\mathrm{Mg}^{2+}$ level in the feed water, thereby augmenting the $\mathrm{Mg}^{2+}$ level 


\subsection{Implications}

Resource recovery from dairy manure presents a potentially renewable source of nutrients. Approximately $15 \%-20 \%$ of the world's phosphorus demand could be achieved by recovering phosphorus from wastewater streams [41]. The concept of using FO membranes to concentrate the wastewater to facilitate struvite recovery from dairy manure can be utilised for phosphate fertiliser production. According to our study, compared to $\mathrm{NaCl}$ and EDTA$2 \mathrm{Na}, \mathrm{MgCl}_{2}$ could achieve a better water flux and concentrated feed solution with lower salinity but without losing the available $\mathrm{PO}_{4}{ }^{3-}, \mathrm{NH}_{3}-\mathrm{N}$ and $\mathrm{Mg}^{2+}$. Since a high water flux along with low reverse solute flux is a major requirement for the FO technology for reducing replenishment costs and salinity build-up, $\mathrm{MgCl}_{2}$ can be recommended for phosphorus recovery from ATDM. However, the comparably higher cost of the magnesium salts [42] may be a potential barrier for the scale-up of this process. A comprehensive cost comparison would be helpful, but that is beyond the scope of this study.

In the FO process, water drawn from the feed side goes to a highly saline draw solution. Since FO itself does not produce fresh water, the management of the diluted draw solution is 


\section{Conclusions}

The present study compared the performance of three draw solutions to concentrate phosphorous from anaerobically treated dairy manure (ATDM) via FO process and subsequently recover it as struvite crystals. The FO membrane was able to effectively reject $\mathrm{PO}_{4}{ }^{3-}$ and $\mathrm{Mg}^{2+}$ and contribute to their enrichment in ATDM. The FO system obtained a $\mathrm{PO}_{4}{ }^{3-}$ concentration factor of 2.5 at a water recovery rate of $60 \%$. Both $\mathrm{MgCl}_{2}$ and EDTA- 
$2 \mathrm{Na}$ as draw solutes were more efficient than $\mathrm{NaCl}$ in reducing the level of salinity build-up in the concentrated ATDM. This was attributed to their lower reverse solute fluxes. $\mathrm{MgCl}_{2}$ enhanced the pre-concentration of dairy manure for struvite precipitation more effectively than the other draw solutes. This is because the elevated $\mathrm{pH}$ and higher $\mathrm{Mg}^{2+}$ concentrations achieved in case of $\mathrm{MgCl}_{2}$ enabled bi-directional transport of protons from the dairy manure and thus enhanced the struvite precipitation kinetics. Notably, supersaturation of various chemical species close to the membrane surface may lead to their precipitation onto the membrane surface, causing membrane fouling. It is recommended that the future studies address this issue, but this is beyond the scope of the current study. Moreover, the applicability of these processes needs to be systematically evaluated at pilot- and full-scales along with an economic evaluation.

\section{Acknowledgements}

A Vice-Chancellor's Postdoctoral Research Fellowship to Dr Biplob Kumar Pramanik by the University of Wollongong, Australia is gratefully acknowledged.

\section{References}

[1] S.O. Petersen, S. Sommer, F. Béline, C. Burton, J. Dach, J. Dourmad, A. Leip, T. Misselbrook, F. Nicholson, H.D. Poulsen, Livestock Science, 112 (2007) 180-191.

[2] Y. Liu, J.-H. Kwag, J.-H. Kim, C. Ra, Desalination, 277 (2011) 364-369.

[3] L. Wang, Y. Li, P. Chen, M. Min, Y. Chen, J. Zhu, R.R. Ruan, Bioresource Technology, 101 (2010) 2623-2628.

[4] A.C. Wilkie, W.W. Mulbry, Bioresource Technology, 84 (2002) 81-91.

[5] N. Morales, M.A. Boehler, S. Buettner, C. Liebi, H. Siegrist, Water, 5 (2013) 1262-1278.

[6] K. Suzuki, Y. Tanaka, K. Kuroda, D. Hanajima, Y. Fukumoto, T. Yasuda, M. Waki, Bioresource Technology, 98 (2007) 1573-1578.

[7] O. Ichihashi, K. Hirooka, Bioresource Technology, 114 (2012) 303-307.

[8] A. Britton, F.A. Koch, D.S. Mavinic, A. Adnan, W.K. Oldham, B. Udala, Journal of Environmental Engineering and Science, 4 (2005) 265-277.

[9] M. Gerardo, M. Zacharof, R. Lovitt, Water Research, 47 (2013) 4833-4842.

[10] L.D. Xavier, M.C. Cammarota, L. Yokoyama, I. Volschan, Water Science and Technology, 69 (2014) 1546-1551.

[11] A. Triger, J.-S. Pic, C. Cabassud, Water Research, 46 (2012) 6084-6094. 
[12] V. Oliveira, L.M. Ottosen, J. Labrincha, C. Dias-Ferreira, Waste and Biomass Valorization, 7 (2016) 861-869.

[13] G. Barnett, Bioresource Technology, 49 (1994) 139-147.

[14] K. Güngör, K. Karthikeyan, Bioresource Technology, 99 (2008) 425-436.

[15] T. Zhang, K.E. Bowers, J.H. Harrison, S. Chen, Water Environment Research, 82 (2010) 34-42.

[16] A.J. Ansari, F.I. Hai, W.E. Price, J.E. Drewes, L.D. Nghiem, Journal of Membrane Science, 529 (2017) 195-206.

[17] J.R. McCutcheon, M. Elimelech, Journal of Membrane Science, 284 (2006) 237-247.

[18] K. Lutchmiah, A. Verliefde, K. Roest, L.C. Rietveld, E.R. Cornelissen, Water Research, 58 (2014) 179-197.

[19] T.-S. Chung, S. Zhang, K.Y. Wang, J. Su, M.M. Ling, Desalination, 287 (2012) 78-81.

[20] B.K. Pramanik, F.I. Hai, F.A. Roddick, Separation and Purification Technology, 217 (2019) 215220.

[21] M. Xie, L.D. Nghiem, W.E. Price, M. Elimelech, Environmental Science \& Technology Letters, 1 (2014) 191-195.

[22] W. Xue, T. Tobino, F. Nakajima, K. Yamamoto, Water Research, 69 (2015) 120-130.

[23] W. Luo, F.I. Hai, W.E. Price, W. Guo, H.H. Ngo, K. Yamamoto, L.D. Nghiem, Bioresource Technology, 200 (2016) 297-304.

[24] J. Zhang, Q. She, V.W. Chang, C.Y. Tang, R.D. Webster, Environmental Science and Technology, 48 (2014) 3386-3394.

[25] A.J. Ansari, F.I. Hai, W.E. Price, L.D. Nghiem, Separation and Purification Technology, 163 (2016) 1-7.

[26] J. Minier-Matar, A. Santos, A. Hussain, A. Janson, R. Wang, A.G. Fane, S. Adham, Environmental Science \& Technology, 50 (2016) 6044-6052.

[27] R. Longhurst, A. Roberts, M. O'Connor, New Zealand Journal of Agricultural Research, 43 (2000) 7-14.

[28] G. Ward, J. Jacobs, in Effectiveness of dairy first pond sludge as a nutrient source for forage crop production, Australian Society of Agronomy, Adelaide (2006).

[29] J. Fyfe, D. Hagare, M. Sivakumar, Journal of Environmental Management, 180 (2016) 133-146.

[30] N.Y. Yip, A. Tiraferri, W.A. Phillip, J.D. Schiffman, M. Elimelech, Environmental Science \& Technology, 44 (2010) 3812-3818.

[31] Y. Xu, X. Peng, C.Y. Tang, Q.S. Fu, S. Nie, Journal of Membrane Science, 348 (2010) 298-309.

[32] K. Lutchmiah, J.W. Post, L.C. Rietveld, E.R. Cornelissen, Water Science \& Technology, 70 (2014) 1677-1682.

[33] Y.-L. Ji, B.-X. Gu, Q.-F. An, C.-J. Gao, Polymers, 9 (2017) 715.

[34] J.T. Arena, S.S. Manickam, K.K. Reimund, B.D. Freeman, J.R. McCutcheon, Desalination, 343 (2014) 8-16.

[35] Q. She, X. Jin, Q. Li, C.Y. Tang, Water Research, 46 (2012) 2478-2486.

[36] X. Lu, C. Boo, J. Ma, M. Elimelech, Environmental Science \& Technology, 48 (2014) 14369-14376.

[37] J.-J. Qin, M.H. Oo, M.N. Wai, F.-S. Wong, Journal of Membrane Science, 217 (2003) 261-268.

[38] Z. Wang, J. Zheng, J. Tang, X. Wang, Z. Wu, Scientific reports, 6 (2016) 21653.

[39] N.T. Hau, S.-S. Chen, N.C. Nguyen, K.Z. Huang, H.H. Ngo, W. Guo, Journal of Membrane Science, 455 (2014) 305-311.

[40] M.Y. Kiriukhin, K.D. Collins, Biophysical Chemistry, 99 (2002) 155-168.

[41] Z. Yuan, S. Pratt, D.J. Batstone, Current opinion in biotechnology, 23 (2012) 878-883.

[42] Z. Bradford-Hartke, J. Lane, P. Lant, G. Leslie, Environmental Science \& Technology, 49 (2015) 8611-8622.

[43] Q. Long, Y. Jia, J. Li, J. Yang, F. Liu, J. Zheng, B.J.P. Yu, 6 (2018) 165.

[44] P. Pal, P. Das, S. Chakrabortty, R. Thakura, Environmental Science and Pollution Research, 23 (2016) 21604-21618. 
[45] R. Thiruvenkatachari, M. Francis, M. Cunnington, S. Su, Separation and Purification Technology, 163 (2016) 181-188.

[46] Q. Ge, M. Ling, T.-S. Chung, J Journal of Membrane Science, 442 (2013) 225-237.

[47] V. Yangali-Quintanilla, Z. Li, R. Valladares, Q. Li, G.J.D. Amy, 280 (2011) 160-166.

[48] S. Adham, A. Hussain, J.M. Matar, R. Dores, A.J.D. Janson, 314 (2013) 101-108.

[49] M. El-Bourawi, Z. Ding, R. Ma, M.J.J.o.m.s. Khayet, 285 (2006) 4-29.

[50] S.K. Yen, M. Su, K.Y. Wang, T.-S.J.J.o.M.S. Chung, 364 (2010) 242-252.

[51] D. Zhao, S. Chen, P. Wang, Q. Zhao, X.J.I. Lu, E.C. Research, 53 (2014) 16170-16175.

[52] S. Zhang, P. Wang, X. Fu, T.-S.J.w.r. Chung, 52 (2014) 112-121.

[53] M. Xie, L.D. Nghiem, W.E. Price, M. Elimelech, Environmental Science \& Technology, 47 (2013) 13486-13493. 


\section{List of Figure Captions}

Figure 1: (a) Impact of draw solutes on normalized flux during filtration of ATDM, (b) average water flux and reverse solute flux of $\mathrm{MgCl}_{2}, \mathrm{NaCl}$, and EDTA-2Na draw solution at 90 bar osmotic pressure where feed solution was DI water. RSFS denotes the volume of permeate water per gram of solute that has diffused from the draw solution to the feed solution.

Figure 2: Variation of feedwater (a) conductivity, (b) $\mathrm{pH}$ and (c) $\mathrm{Mg}^{2+}$ concentration during anaerobically treated dairy manure pre-concentration for $\mathrm{NaCl}, \mathrm{MgCl}_{2}$, and EDTA-2Na draw solution (values indicate average \pm standard deviation of duplicate samples).

Figure 3: Variation of concentration and rejection of (a) $\mathrm{COD}$, (b) $\mathrm{NH}_{3}-\mathrm{N}$, (c) $\mathrm{NO}_{3}{ }^{-}$, (d) $\mathrm{TN}$, and (e) $\mathrm{PO}_{4}{ }^{3-}$ during pre-concentration of anaerobically treated dairy manure at different water recovery (values indicate average \pm standard deviation of duplicate samples).

Figure 4: (a) Image produced by scanning electron microscopy, (b) energy dispersive X-ray spectrometry spectra of the recovered solids for different draw solutions

Figure 5: (a) Purity of struvite crystal analysis for different draw solutions using XRD analysis, and (b) elementary composition of recovered crystals analysis using ICP-OES for $\mathrm{Mg}^{2+}$ and Hach spectrophotometer for $\mathrm{PO}_{4}{ }^{3-}$ and $\mathrm{NH}_{3}-\mathrm{N}$ (data points are average values of duplicate samples). 

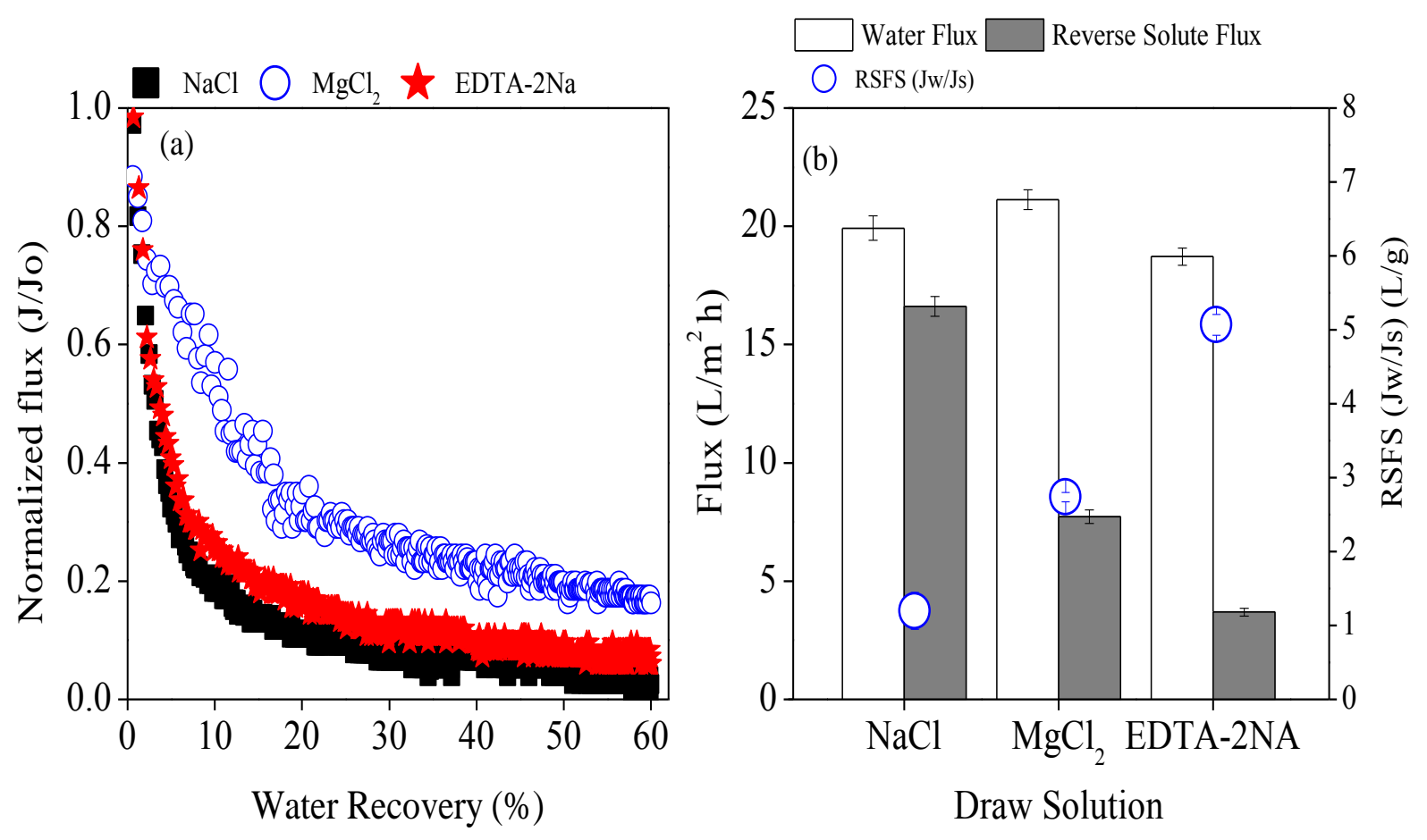

Figure 1 

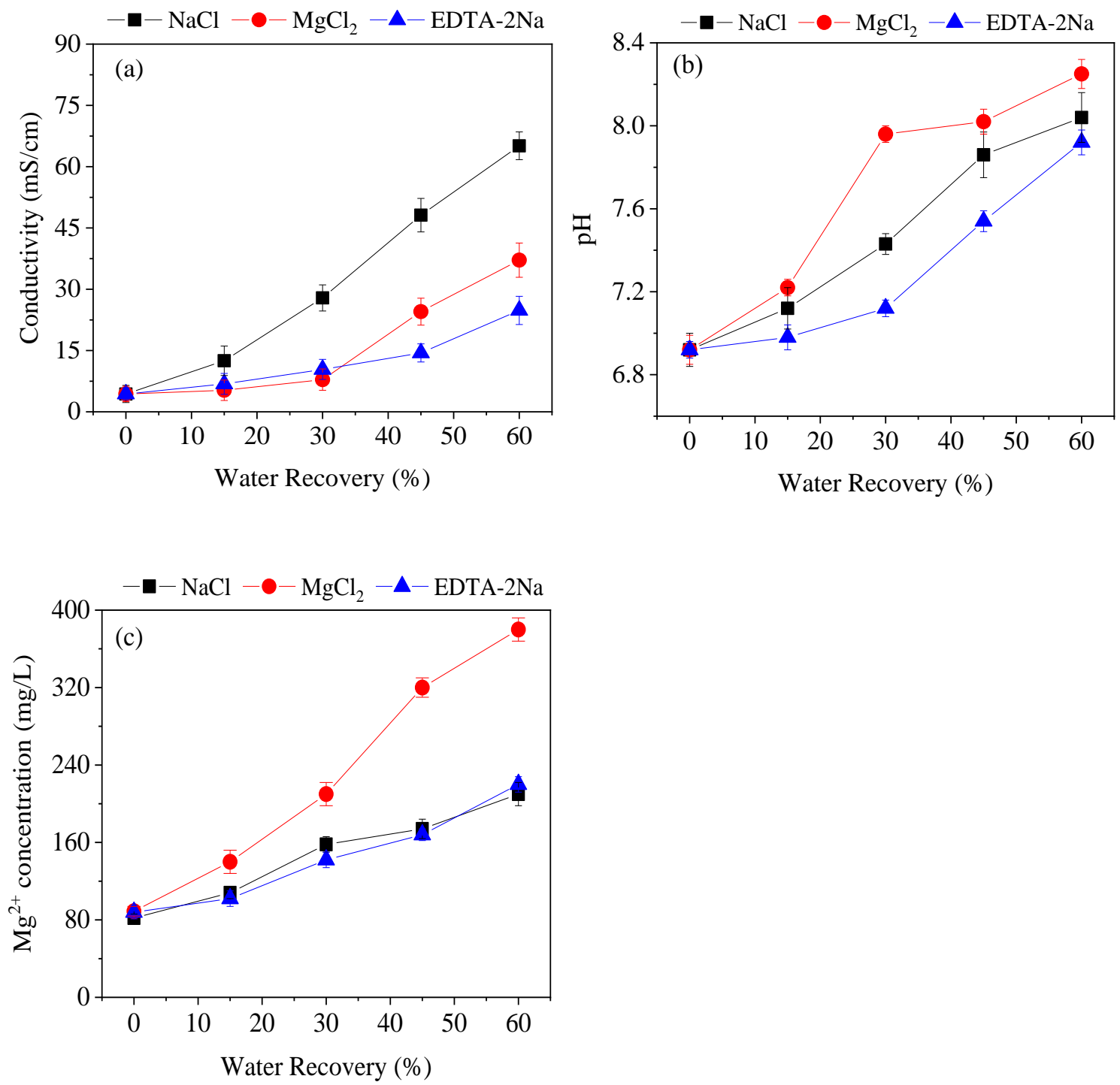

Figure 2 

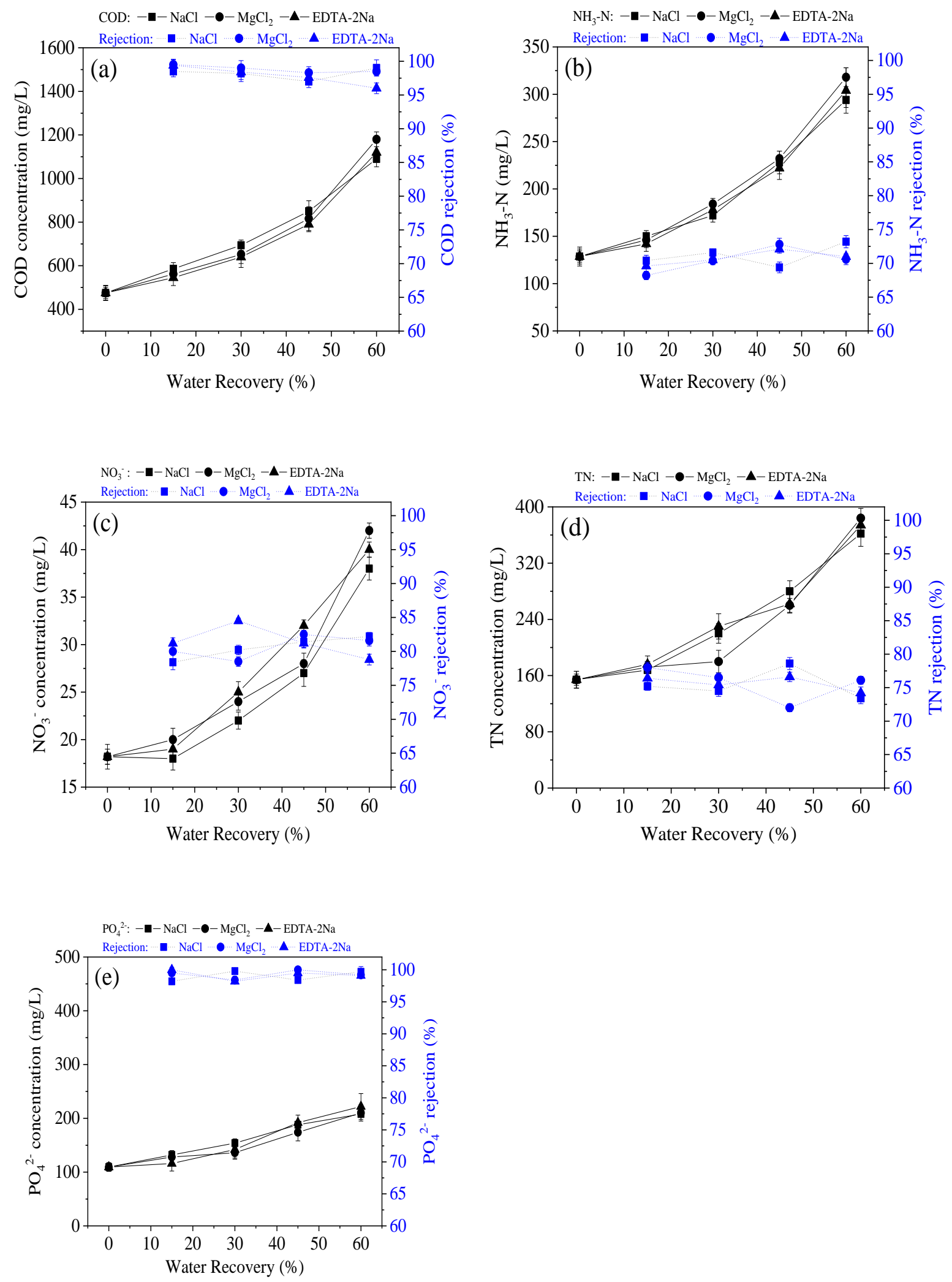

Figure 3 
(a)
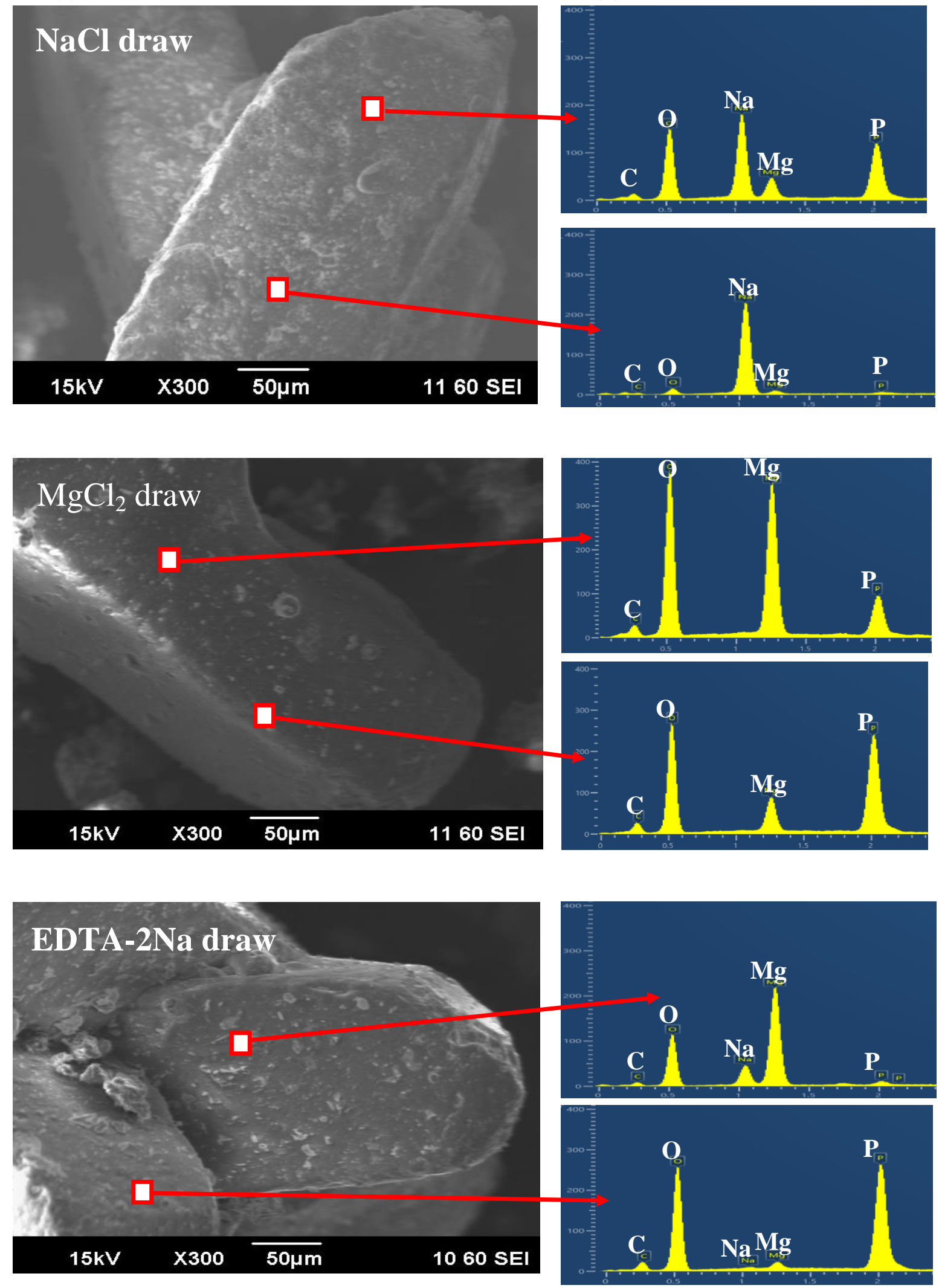

Figure 4 
(a)
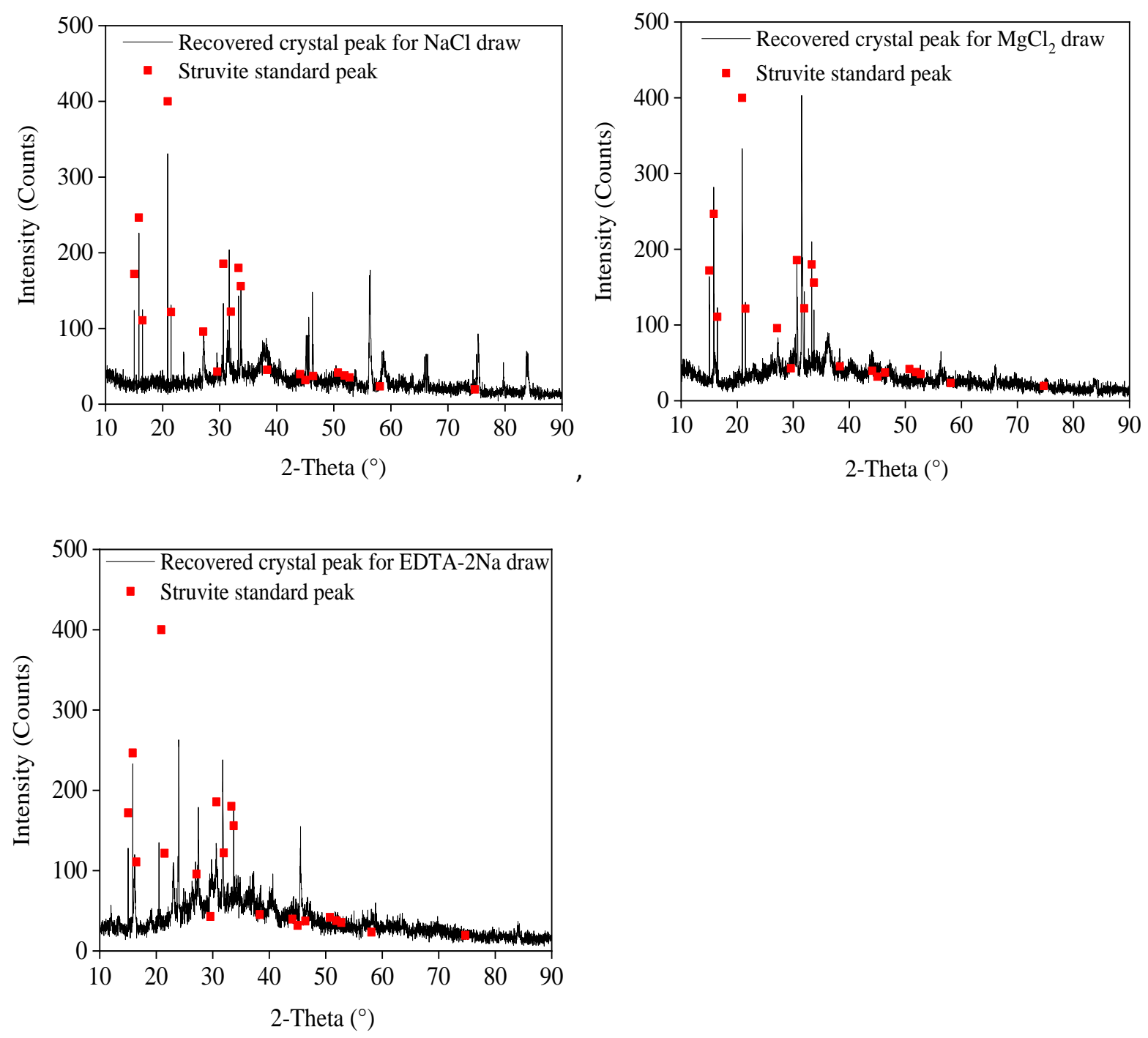

(b)

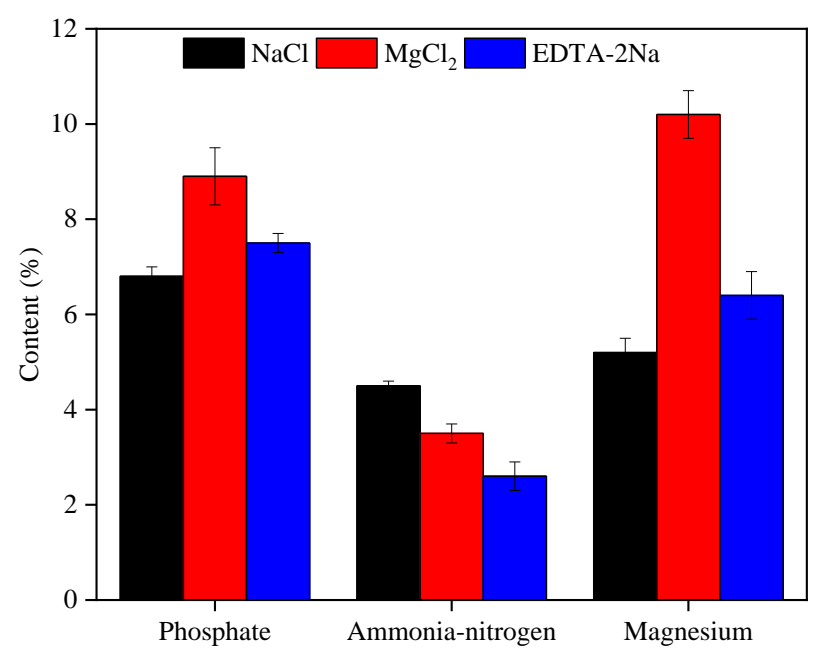

Figure 5 


\section{Supplementary Information}

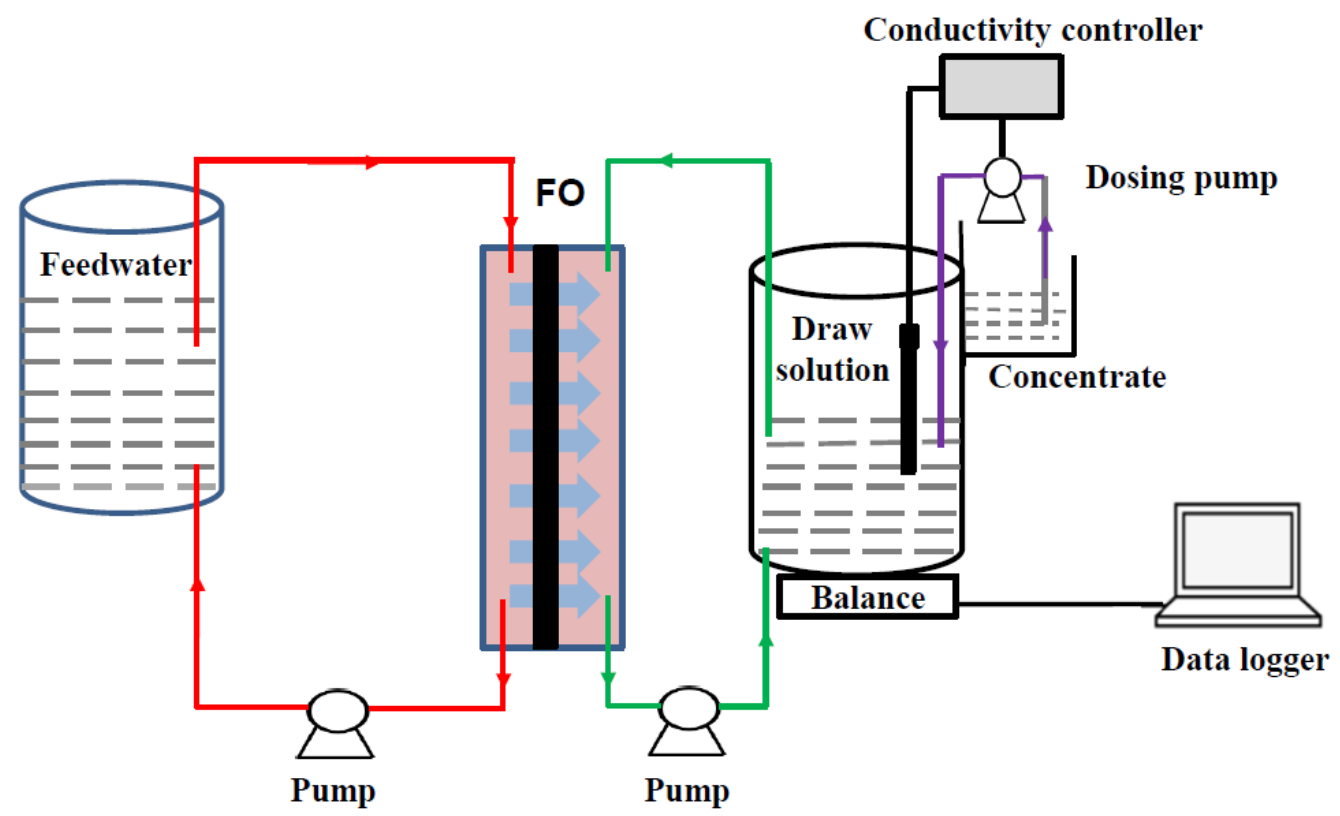

Figure S1: A schematic diagram of the lab-scale FO system 
Table S1: Properties of the TFC membrane (Zheng et al., 2018)
Properties
Value
Pore radius (nm)
$0.37 \pm 0.04$
Water permeability coefficient $\left(\mathrm{L} / \mathrm{m}^{2} \mathrm{~h}\right.$. bar $)$
$3.2 \pm 0.22$
Salt $(\mathrm{NaCl})$ permeability coefficient $\left(\mathrm{L} / \mathrm{m}^{2} \mathrm{~h}\right)$
$0.41 \pm 0.01$
Membrane structure parameter $(\mathrm{mm})$
$0.46 \pm 0.05$
Zeta potential $(\mathrm{mV})$
$-16.2$
Contact angle (active layer) $\left(^{\circ}\right)$
$49.5 \pm 3.4$

Zheng, L., Price, W.E., Nghiem, L.D. 2018. Effects of fouling on separation performance by forward osmosis: the role of specific organic foulants. Environmental Science and Pollution Research, 1-12. 


\section{Graphical Abstract}

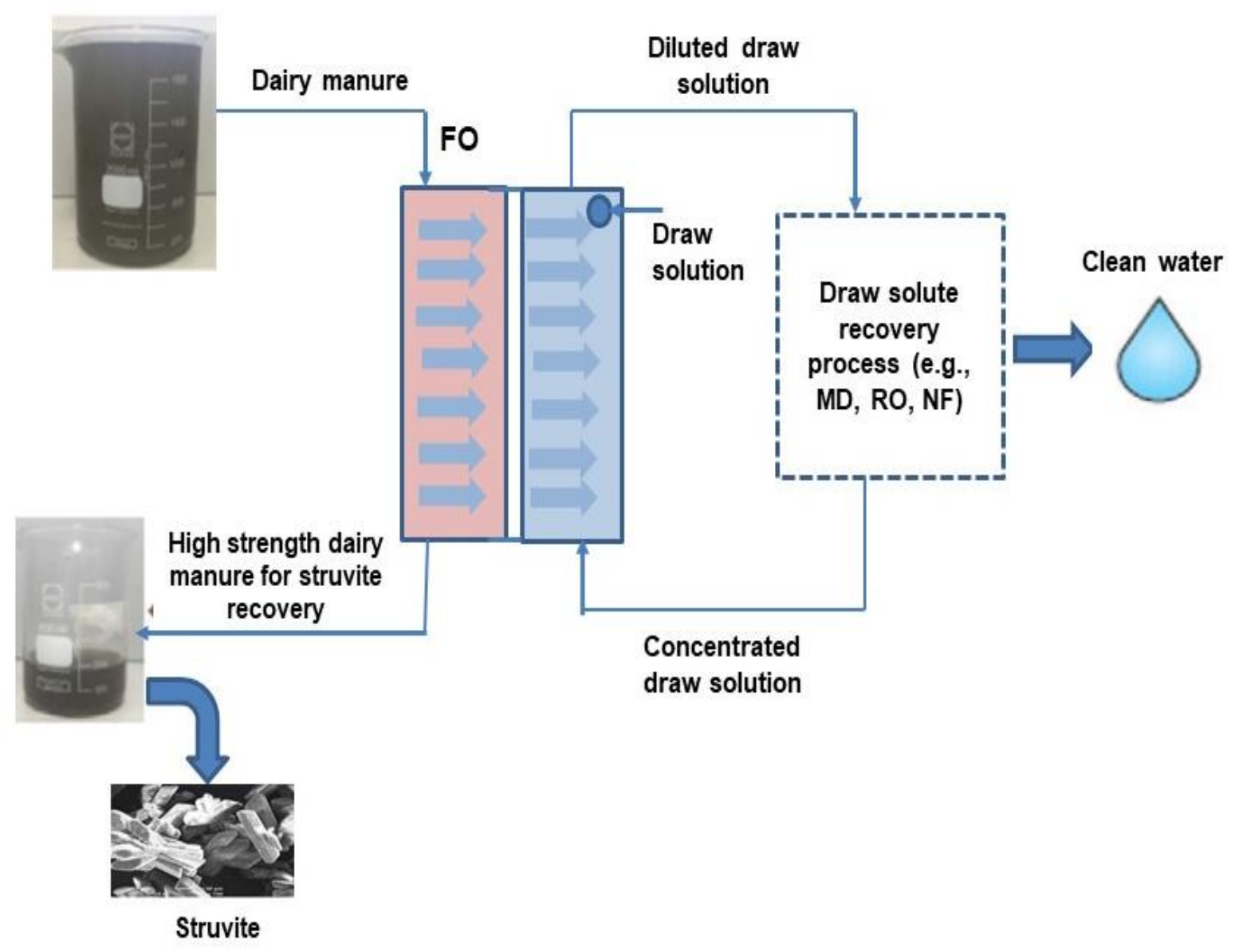


Table 1: Characteristics of the dairy manure before and after treatments (values indicate average \pm standard deviation of duplicate samples)

\begin{tabular}{llll}
\hline Parameter & Raw wastewater & Anaerobic pond effluent & Aerobic pond effluent \\
\hline $\mathrm{COD}(\mathrm{mg} / \mathrm{L})$ & $1240 \pm 88$ & $475 \pm 24$ & $306 \pm 18$ \\
$\mathrm{NH}_{3}-\mathrm{N}(\mathrm{mg} / \mathrm{L})$ & $176 \pm 12$ & $128 \pm 11$ & $88 \pm 6$ \\
$\mathrm{NO}_{3}{ }^{-}(\mathrm{mg} / \mathrm{L})$ & $26 \pm 3$ & $18 \pm 2$ & $16 \pm 4$ \\
$\mathrm{TN}(\mathrm{mg} / \mathrm{L})$ & $212 \pm 24$ & $154 \pm 18$ & $116 \pm 16$ \\
$\mathrm{PO}_{4}{ }^{3-}(\mathrm{mg} / \mathrm{L})$ & $112 \pm 8$ & $109 \pm 8$ & $78 \pm 6$ \\
$\mathrm{pH}$ & $6.76 \pm 0.02$ & $6.92 \pm 0.02$ & $7.18 \pm 0.03$ \\
$\mathrm{TSS}(\mathrm{mg} / \mathrm{L})$ & $2476 \pm 312$ & $516 \pm 128$ & $346 \pm 96$ \\
$\mathrm{EC}(\mathrm{mS} / \mathrm{cm})$ & $4.58 \pm 0.24$ & $4.36 \pm 0.12$ & $4.12 \pm 0.16$ \\
$\mathrm{DO}^{2}(\mathrm{mg} / \mathrm{L})$ & $2.32 \pm 0.12$ & - & $1.04 \pm 0.10$ \\
$\mathrm{Mg}^{2+}(\mathrm{mg} / \mathrm{L})$ & $62 \pm 3$ & $82 \pm 3$ & $74 \pm 3$ \\
$\mathrm{Ca}^{2+}(\mathrm{mg} / \mathrm{L})$ & $56 \pm 3$ & $68 \pm 4$ & $62 \pm 5$ \\
$\mathrm{Na}^{+}(\mathrm{mg} / \mathrm{L})$ & $152 \pm 10$ & $146 \pm 6$ & $158 \pm 12$ \\
\hline
\end{tabular}

